\title{
Sustainable Housing Landscape Concept as a Source of Wrapping Materials for Preserving Culture Activities in Malay Traditional Food
}

\author{
Mhd Nor Osman ${ }^{1}$, Anwar Fikri Abdullah ${ }^{2}$ \& Muhamad Abd Aziz Ab Gani ${ }^{3}$ \\ Universiti Teknologi MARA Perak Branch, Seri Iskandar Campus, 32610 Seri Iskandar, Perak, \\ MALAYSIA \\ mhdno683@perak.uitm.edu.my ${ }^{1}$ anwar575@perak.uitm.edu.my² aziz354@perak.uitm.edu.my ${ }^{3}$
}

Published: 7 September 2018

\begin{abstract}
In the Malay community, traditional food packaging is made from a variety of natural ingredients / leaves. The interesting aspect of Malay cakes in the Malay Archipelago is the type of leaves used to wrap food. Examples of leaves used are: banana leaf, upih pinang, baharu leaves, ketapang leaves, yam leaves, pandanus leaves, coconut leaves and rubber tree leaves. However, among these ingredients, banana leaves are very popular and most widely used as wrappers for some Malay food and cakes as wrappers. Uniquely, each type of cake has its own packaging and technique methods, even using the same material from the wrapping material. More unique are some traditional kueh that use coconut leaf and have to go through the woven process to make cone or casing. This privilege requires a skill not everyone, especially this generation. He should be taught this knowledge of woven art I wrapping and the cultural elements behind him will be transferred to a new generation. If not preserved, the country will lose its cultural identity. Modern packaging are using plastic and PVC materials threatens our culture and yet this material will worsen the quality of environmental pollution if the disposal of this waste is not properly managed. In order to pursue this traditional culture, the community is encouraged to plant trees that can be used as packaging of this tradition, around the house and yet contributed for environmental sustainability.

Keywords: Traditional food wrapping, natural ingredients, uniqueness, cultural identity, environmental sustainability.

eISSN: 2550-214X (C) 2018. The Authors. Published for Idealogy Journal of Arts and Social Science by UiTM Press. This is an Open Access article distributed under the terms of the Creative Commons Attribution-NonCommercial-NoDerivatives License (http://creativecommons.org/licenses/by-nc-nd/4.0/), which permits non-commercial re-use, distribution, and reproduction in any medium, provided the original work is properly cited, and is not altered, transformed, or built upon in any way.
\end{abstract}

\section{INTRODUCTION}

Art activities among communities in the Malay Archipelago have been recognized worldwide as being very unique and interesting. In this community activity that contains the elements of art are produced through carving, weaving, carpentry, architecture and so on. This art has been fundamental to the culture of their lives for centuries. With this activity, the identity of the community is more visible and attractive to outsiders. According Marzita Putih, et al, (2007), in the community, the arts are divided into two categories: Performing Arts (dance, song, stage performances such as makyong, wayang kulit, ghazal, tambourine, kuda kepang) and Visual Arts (sculpture, art architecture, decorative arts, crafts, and weaving).

Handicraft is a work of art created to be used, but composed by incorporating elements of art to form beautiful and interesting outlooks. Handicraft creation requires expertise and efficiency. According to Siti Zainon Ismail (1986), handicraft creation process requires the power of aesthetics in order to provide a beautiful and interesting design. Malay artwork has its own identity, which also shows a combination of various local elements and influences from abroad. Carving and weaving are part of the traditional art and cannot be separated from the culture and way of life of the Malays. In fact, the art of weaving is part of the Malay life. 
Thus, art and culture as part of the life and identity of the country that need to be protected from the effects of globalization, A Ghafar Ahmad (2004). According to Abdullah A. Badawi (2007), arts, culture and heritage must be preserved from extinction. Noor Nikman Salleh (2009), said that the National Cultural Policy 1971, has outlined that national culture should be based on the culture of the Malays. Meanwhile, the Akta Warisan Kebangsaan (2005), suggests that the study or research of the documentation relating to the elements of culture is very important because it will rebuild a national identity so that it can be maintained, otherwise it will be lost in the course of modernization. Arts and crafts such as weaving mats or baskets have similarities in production processes such as in making Malay traditional cakes which requires the skill to wrap, weave and fold, but only differ in terms of their usage. Therefore, foods such as Malay cakes also can distinguish and identify the community of other races.

The influence of modern wrapped using plastic and contemporary materials and the changed the polar Malays settlements in Malaysia, will affect the younger generation to learn how to wrap traditional foods. This research is to provide knowledge about the culture that has been passed down for over a long period of time. If not preserved, the nation would lose its cultural identity.

\subsection{The Issue}

Since the 1990s, the influence of modern materials using plastic/PVC has taken place in the community. Modern materials are easier and faster to prepare the traditional Malay foods wrapping. The Malay population now lives in the housing estates. There is only have small space to plant trees that can be used as traditional packaging materials such as banana trees or coconut trees and others. This will affect the younger generation to learn from their parents about how to wrap traditional foods and to know the culture elements behind it. This situation is expected to impact the preparation of some traditional foods especially to the next generation.

\subsection{Limitation of the Study}

The study took a few types of packaging materials on traditional Malay cakes in the archipelago as a subject matter in this study. Therefore, the uniqueness which are trying to find out are only focused on these subject matters.

\subsection{Significance of Study}

The study is to ascertain how many members in the family, especially the younger generation know how to wrap or still practice traditional food wrapping using few traditional materials. It should be taught and the knowledge of weaving/wrapping and the culture elements behind it will be transferred to the new generation. If not preserved, the nation would lose its cultural identity.

\subsection{Objectives of the Research}

1. To investigate the knowledge of society on using natural ingredients to wrap Malay traditional foods.

2. To identify whether in Malay societies they still have the kinds of plants that became the source used for traditional cake packaging around their home. 


\subsection{Hypothesis}

There are a lot of natural materials in Malay traditional food packaging which exist and are applied in the daily life of the Malay society. However, the current Malay generation do not realize it and technology has replaced the traditional part of the Malay traditional food packaging. This research will discover the uniquesness types of traditional foods packaging materials in the Malay community.

\section{BACKGROUND}

\subsection{Packaging History}

Around 10,000 years ago, packaging of foods was made from natural ingredients and they were applied and modified from animal skins, stems and leaves of trees. Packaging was generallydivided into two different eras; modern and traditional packaging. Modern packaging usually includes packaging for consumer goods. Gardon, L. R. (2005), states that packaging has been translated as a socio-scientific discipline operating in the community to ensure the smooth delivery of goods to customers. It occurs with the advent of technology, paper and printing industry in the 19th century. Bill, S. (2007) provides that the packaging in pre-modernization era began in 1945. Based on Groth,C. (2006), this is the beginning time line for packaging using modern materials. It continues until now when packaging technology is more innovative in terms of using of materials, functions, and design.

\subsection{The Significance of Traditional Packaging}

The way of life of a society or culture is becoming an identity to a nation. Usually, it is simply and clearly identified by the color, dress, language, behavior, foods, customs and economic activities of a race. Abdullah A Badawi (2007), has reminded the people to defend the nation's cultural and artistic identity of Malaysia/Malay so as not to drown in the global cultural flows. He said, "Development in order to prosper the country cannot run from maintaining the unique identity of the nation of this country is easily recognizable." Food can also distinguish a society of other people. It will be the identity of a community. The identity of a society will usually be inherited and has been the pride of the community, Marzita Puteh et al. (2007).

\subsection{Japanese Traditional Food Packaging/Wrapping}

History has shown that the Japanese are very famous for their traditional packaging using packing materials of natural elements and has the beauty of art. Some foods are packed in a durable manner and can be bought by tourists as souvenirs. According to Yuriko Saito (2007), the Japanese have a clear history and background on the philosophy of food packaging. The Japanese traditional packaging can be considered as a form of art because it features unique design in various forms such as baskets, boxes, wrapping paper, which are still used in everyday life. Hideyuki Oka (2008), explained that the Japanese use rice straw, bamboo, paper and leaves as wrapping materials. They provide onigiri, rice balls, wrapped in bamboo leaf. Bamboo fronds are substances of natural resources that have become popular packaging materials in Japan. It has become a symbol of freshness, because of the aroma of bamboo will seep into the food inside. 


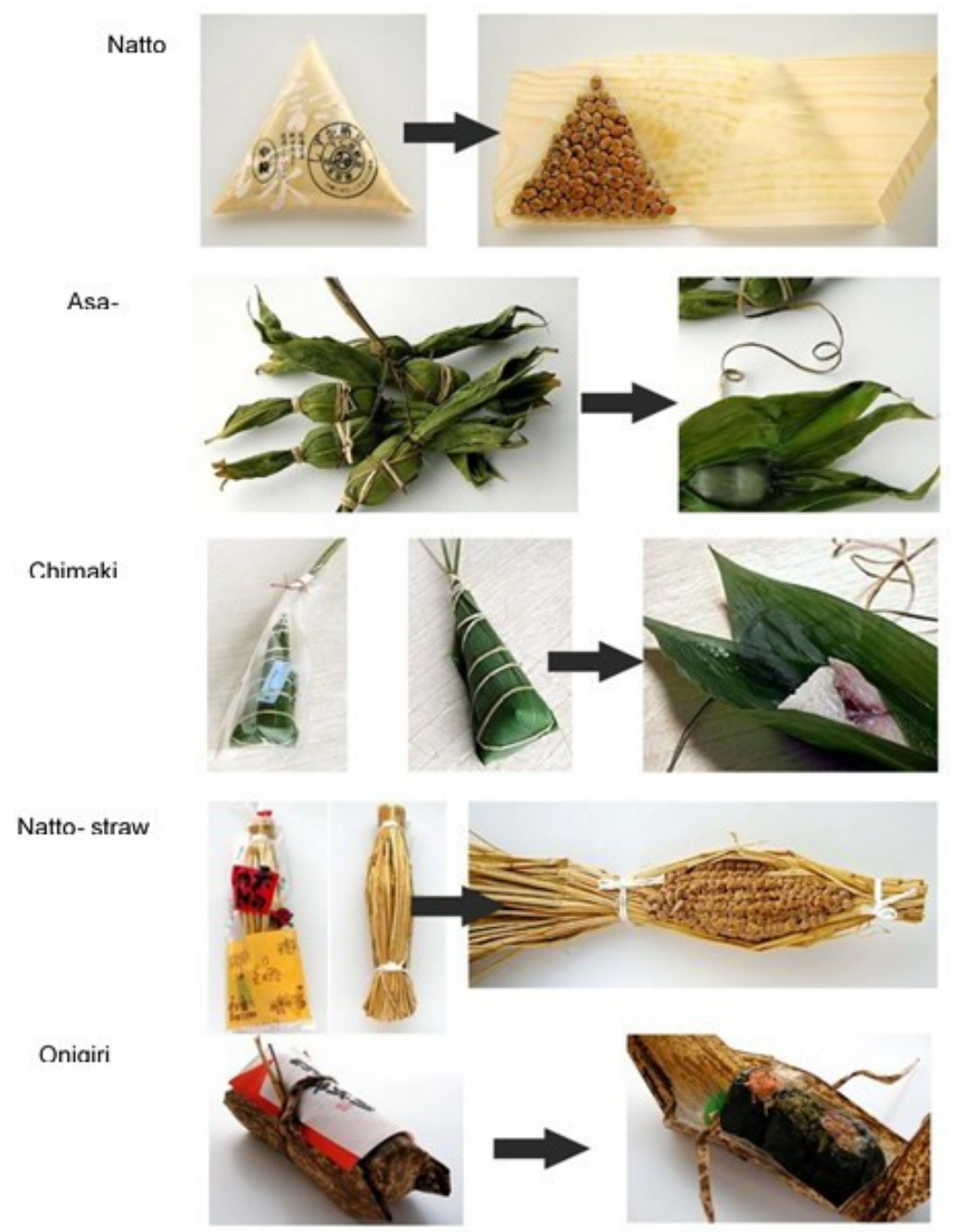

Figure 1: Traditional Japanese foods wrapped by various natural materials

\subsection{Malay Traditional Food Packaging/Wrapping}

The Malays as well as Japanese society is famous for their cuisine, especially cakes $(k u i h)$ or food cooked and served by using a wrapper of natural materials that can be found around the house. (Retrieved from: AbsoluteAstronomy.com, 2009). 

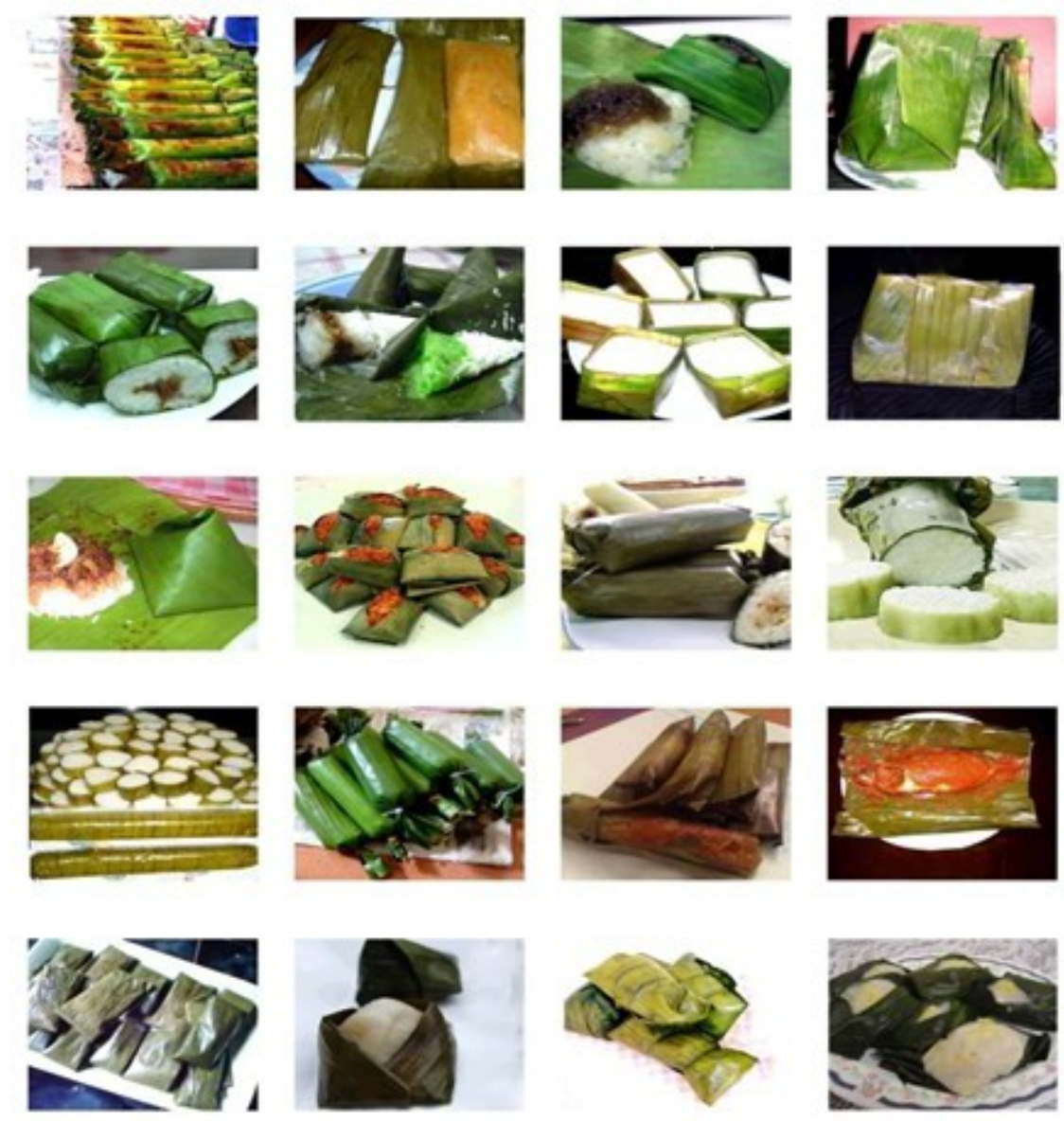

Figure 2: Various traditional Malay cakes (kuih) wrapped in banana leaves

\section{Statements of Problem}

\subsection{The Influence of Modern Packaging}

Since the 1990s, the influence of moden materials wrapped by using plastic material has taken in the community. Modern material is easier and faster to prepare. They are using these materials for preparation of Kuih Tapai, Nasi Lemak and Nasi Himpit, which are now wrapped with plastic and PVC containers. This situation is expected to impact traditional kuih wrapping and weaving especially to the next generation.

Nowadays, plastic packaging has taken over the functions of traditional packaging. With plastic packaging, the aroma and natural smell of packaging materials are missing. There is no longer the taste of the original fragrance of food packaging materials. If the situation continues, people will lose their skills on how to wrap these traditional foods. 

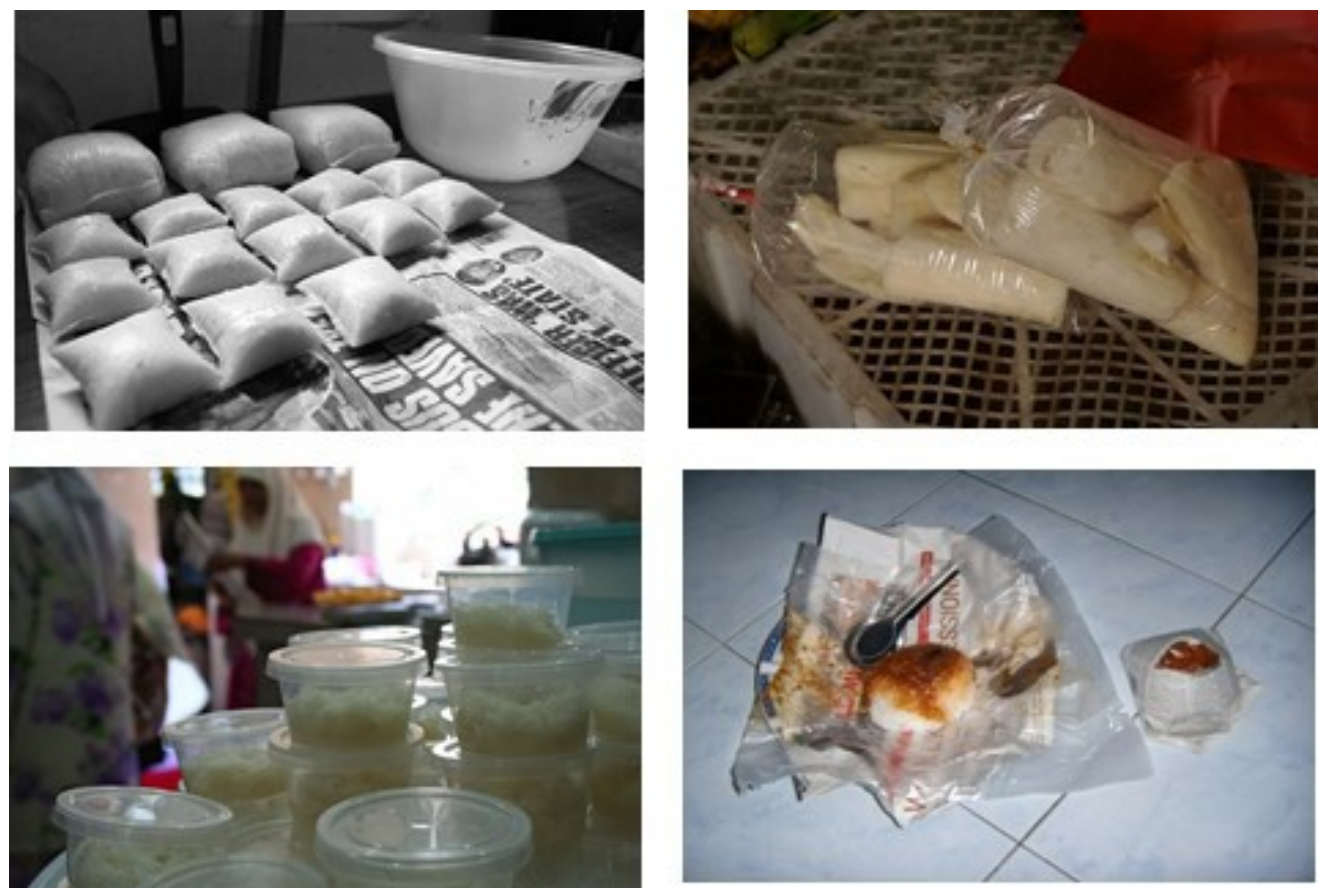

Figure 3: Plastic packaging took over traditional packaging.

\subsection{The Problem of Waste Disposal}

The use of plastic materials is not easy to rot or decompose, it will contribute to environmental degradation. Waste of plastic material is not environmentally friendly and it takes a long time to decompose and disintegrate. As a result, Malaysia is burdened by the cost of managing solid waste disposal and if not managed well, this will cause environmental pollution.

\subsection{Chemicals / Pesticides}

Plastic materials used for packaging foods can cause adverse effects to the human body. According to the Consumers Association of Penang (CAP) S. M. Mohamed Idris (2006), the results of a study by the Institute of Materials Science and Technology, Princeton, USA, revealed that plastic material when at a level of heat will secrete polyethylene (VOC), a type of chemical that can destroy the human hormone that also causes cancer. Similar results were also obtained by Rahmat Awang (2006), from a survey conducted by several scientists from the National Poison Centre (Pusat Racun Negara), Universiti Sains Malaysia, Pulau Pinang, Malaysia.

\subsection{Population and Development}

Rapid development of the Malaysian economic over the last fifty years has changed the polar settlements in Malaysia. Most of the Malay population now lives in housing estates in suburbs and cities, Wan Hashim Wan Teh (1998). These areas do not have enough space to plant trees that can be used as traditional packaging materials such as banana trees or coconut trees. It is different with people who are still living in villages where traditional packaging materials can be found surroundings their homes. 
Consequently, those who live in housing estates have limited opportunities to cook and they only choose foods that do not require such packaging materials. To get traditional packaging materials, they have to go to the market. This situation makes them choose to cook foods that do not use wrapping from leaves. Over time, the younger generation will not learn from their parents how to wrap traditional food. With this situation, this tradition of weaving will not be passed to the new generation, it will be lost to modernity, Hashim Hj. Musa (2005), Hasanah (2008).

\section{MATERIALS TYPE FOR WRAPPING TRADITIONAL FOOD}

In the Malay community, most traditional food packaging/wrapping is made from a variety of natural ingredients/leaves. The Malays are also rich in various kinds of traditional packaging. According to Nik Hassan Suhaimi (2005), the Malays in Peninsular Malaysia is said to be derived from a variety of ethnic hill in the archipelago. He divided the Malays into some ethnic groups' factions, (for example: Aceh, Bugis, Minangkabau, Minang, Banjar, Pattani or Java). Therefore, each ethnic group has its own culinary arts tradition and the identity of privileges for each group.

The interesting aspect about the Malay kuih in the archipelago is in the types of leaves which are used for wrapping food. The leaves are: Lepat wrapped in banana leaves, ketupat palas wrapped in palas leaves, dodol and lempok wrapped with upeh pinang, where tapai also can be wrap either with baharu leaves, ketapang leaves, keladi leaves, banana leaves or rubber tree leaves. Kuih tepung pelita can be wrapped using pandan leaves or banana leaves, while ketupat sate, otak-otak and belebat are packaged in different ways using coconut leaves. Among these materials, banana leaves is very famous and most widely used as wrapping for some Malay foods and cakes. For example, pulut panggang, tepung bungkus, lepat, kuih koci, tepung pelita,tapai, nasi lemak, use banana leaves as a wrapper. Uniquely, each type of kuih has a distinctive way of wrapping methods and techniques, even in using materials from the same wrapping material which is banana leaves.However, more unique of some traditional cakes which are use coconut leaves and have to go through the process of weaving to create a cone or sheath. This uniqueness requires skills that not everyone has, especially this generation.
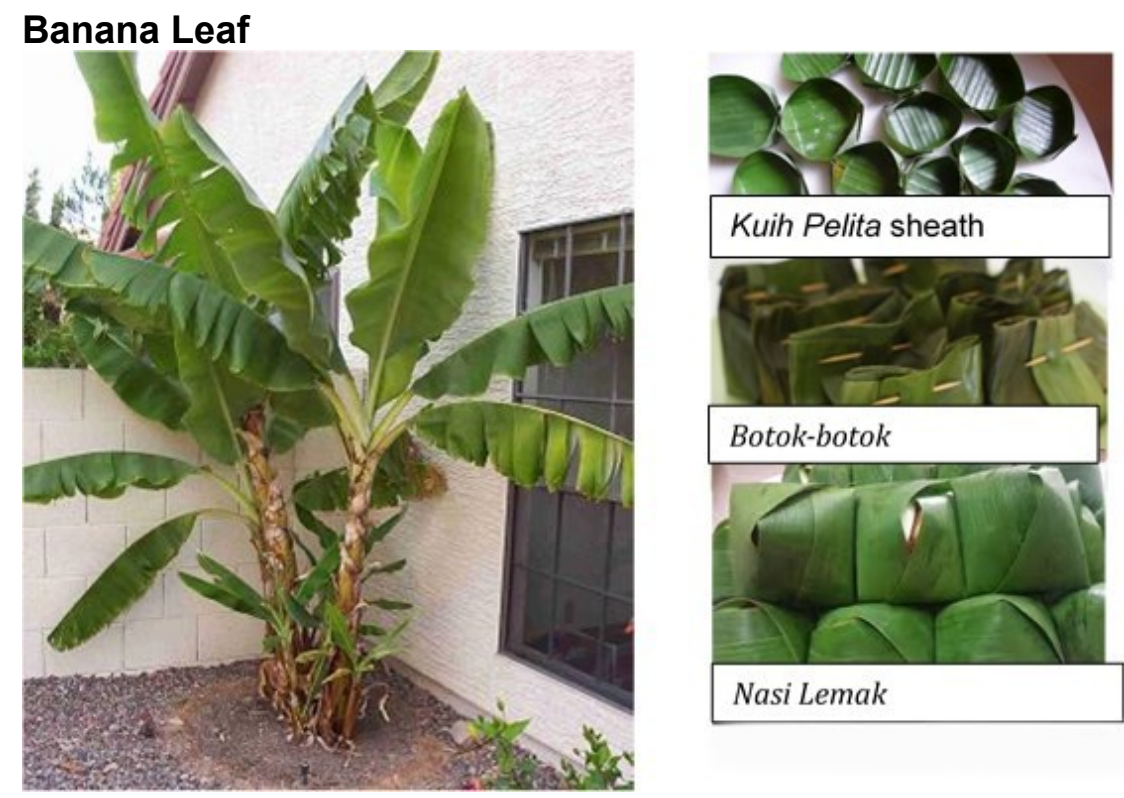


\section{Coconut Leaf}
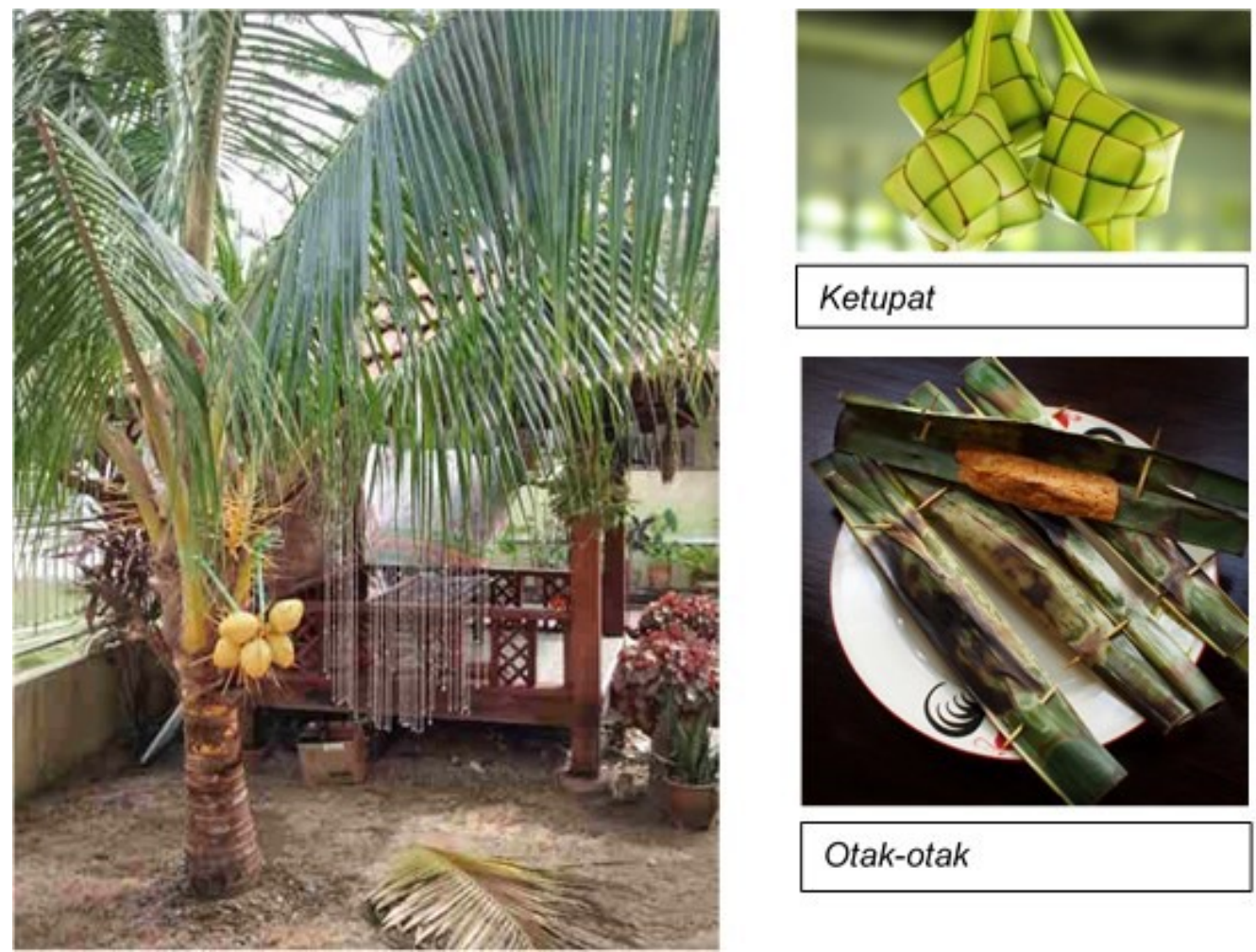

\section{Ketupat}

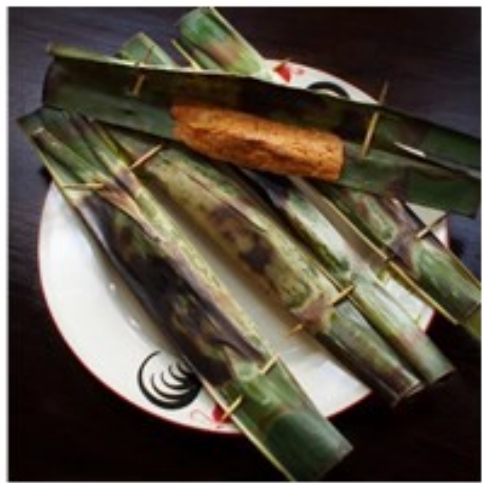

Otak-otak

\section{Palas Leaf}
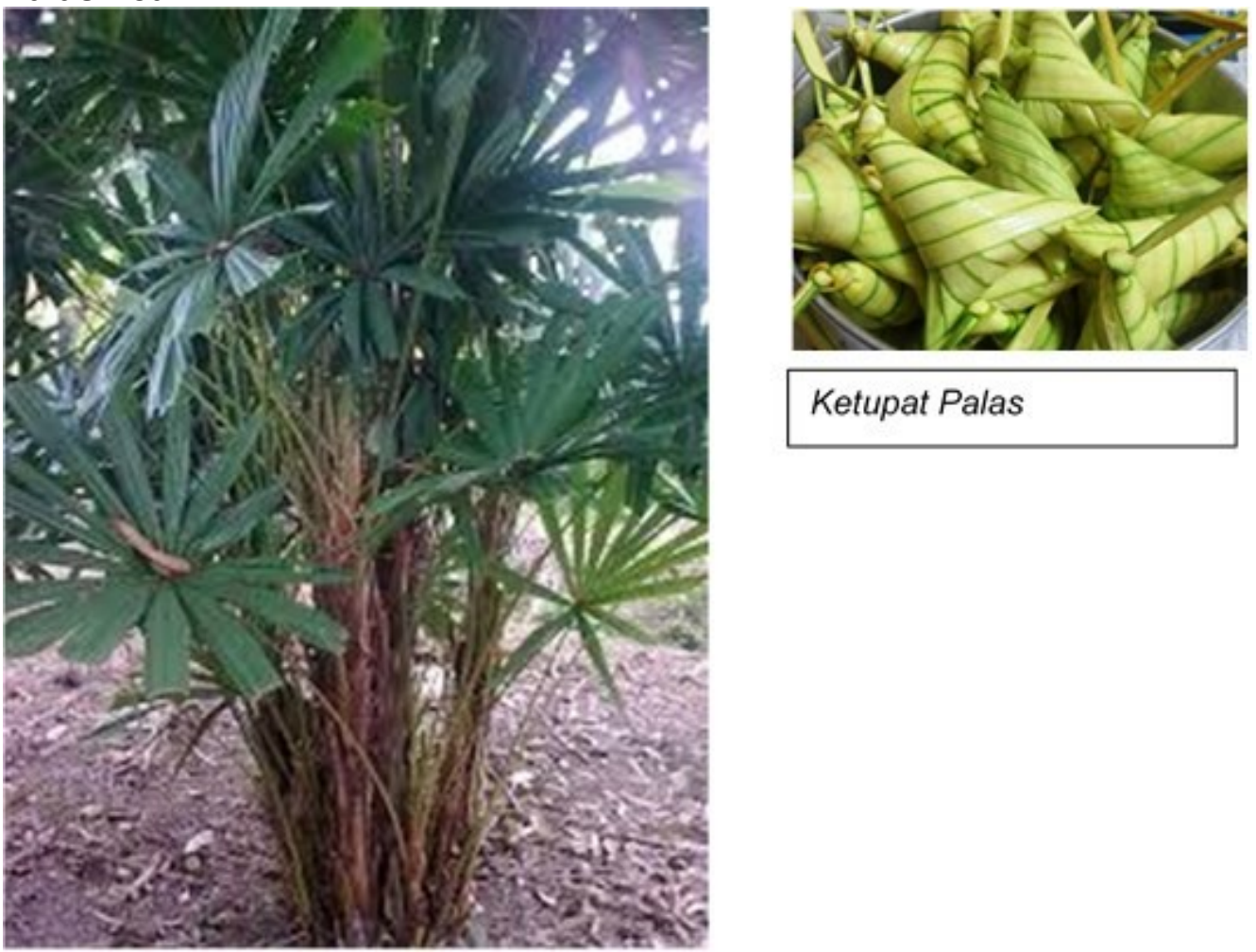

Ketupat Palas 

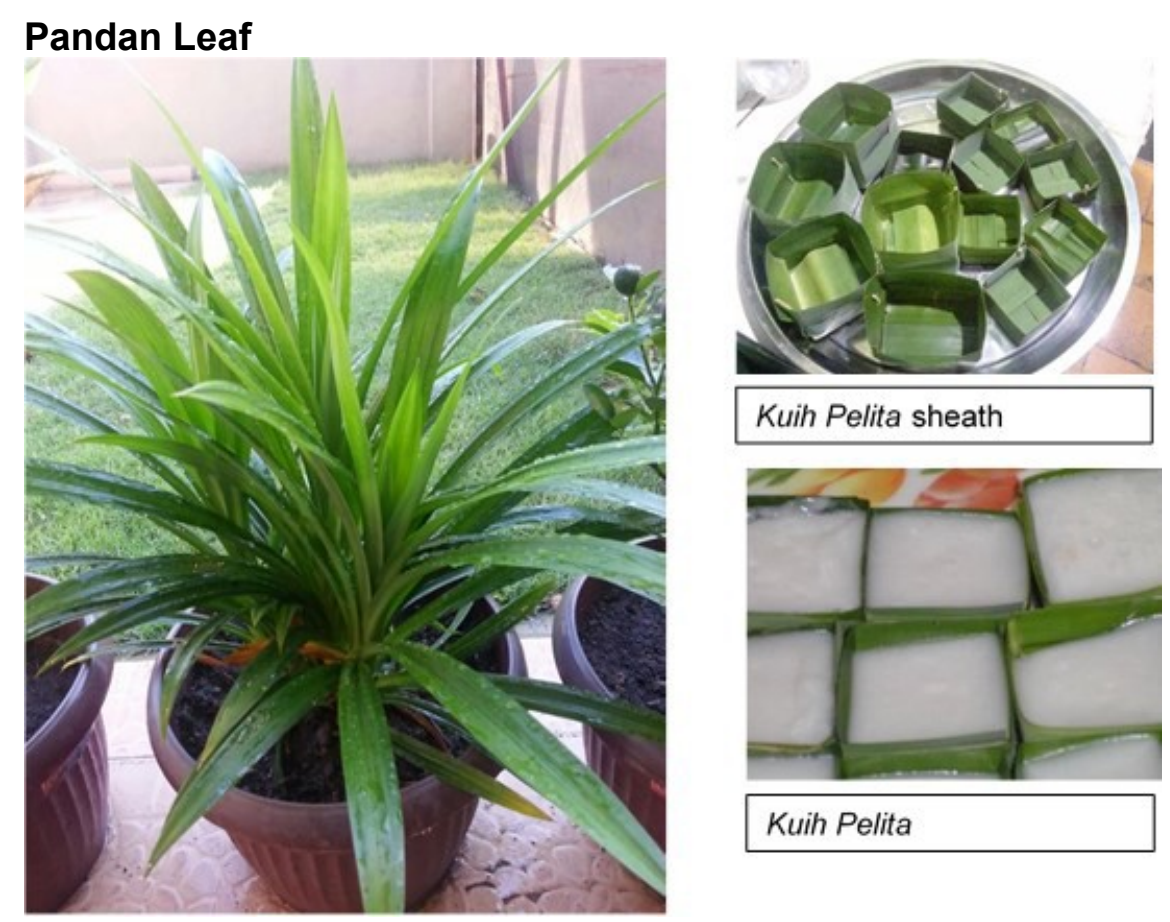

Kuih Pelita

\section{Bamboo Leaf}
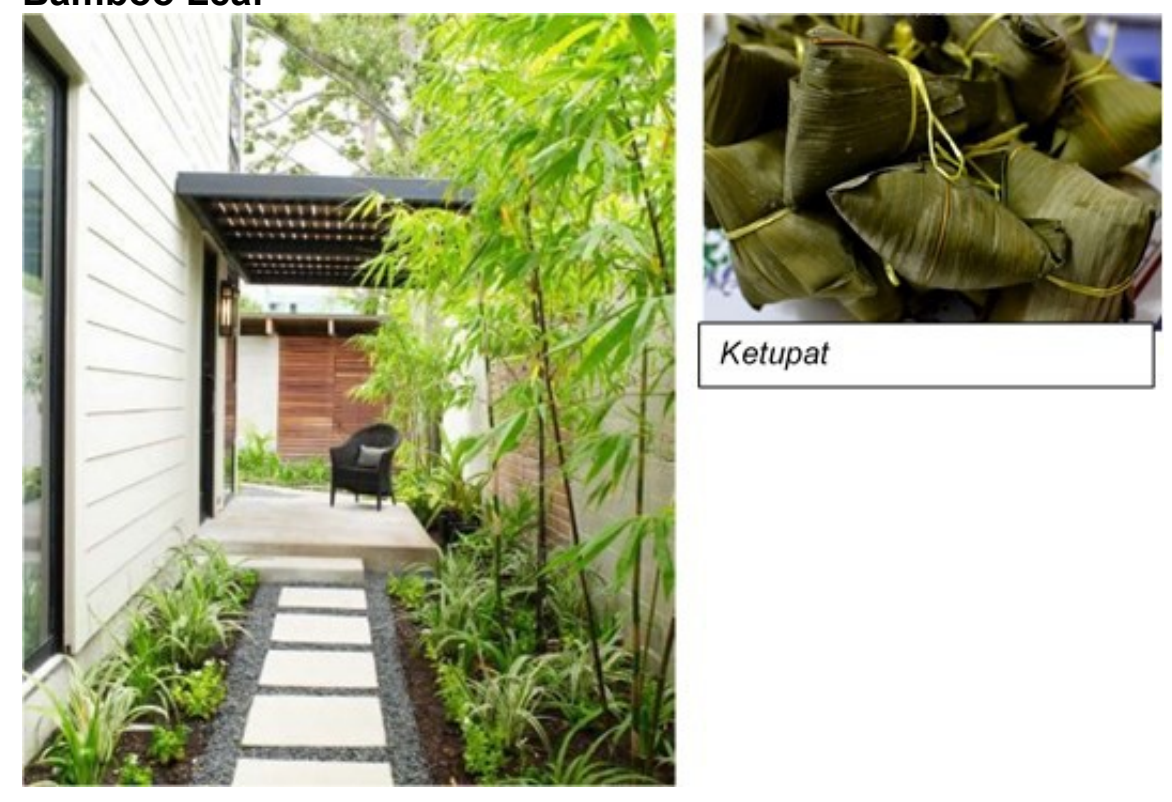

\section{Rubber Tree Leaf}
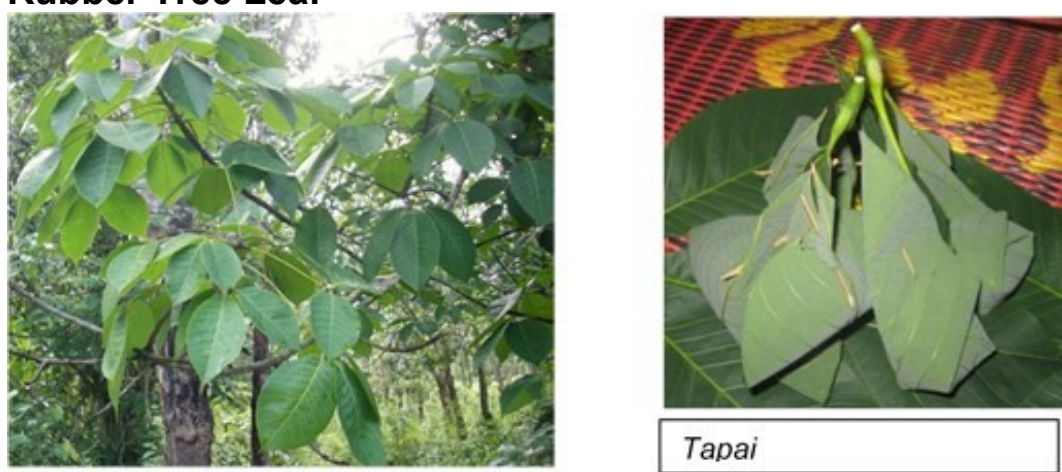

\section{Stumps/Upeh Pinang}



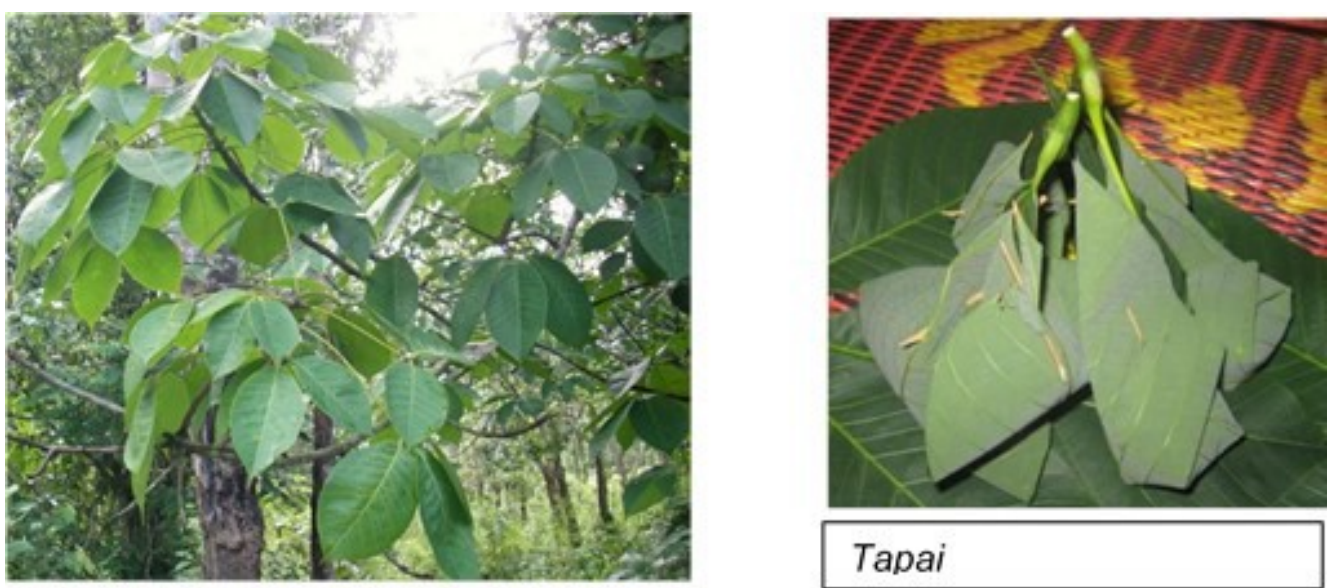

Tapai

\section{Sugar Cane}
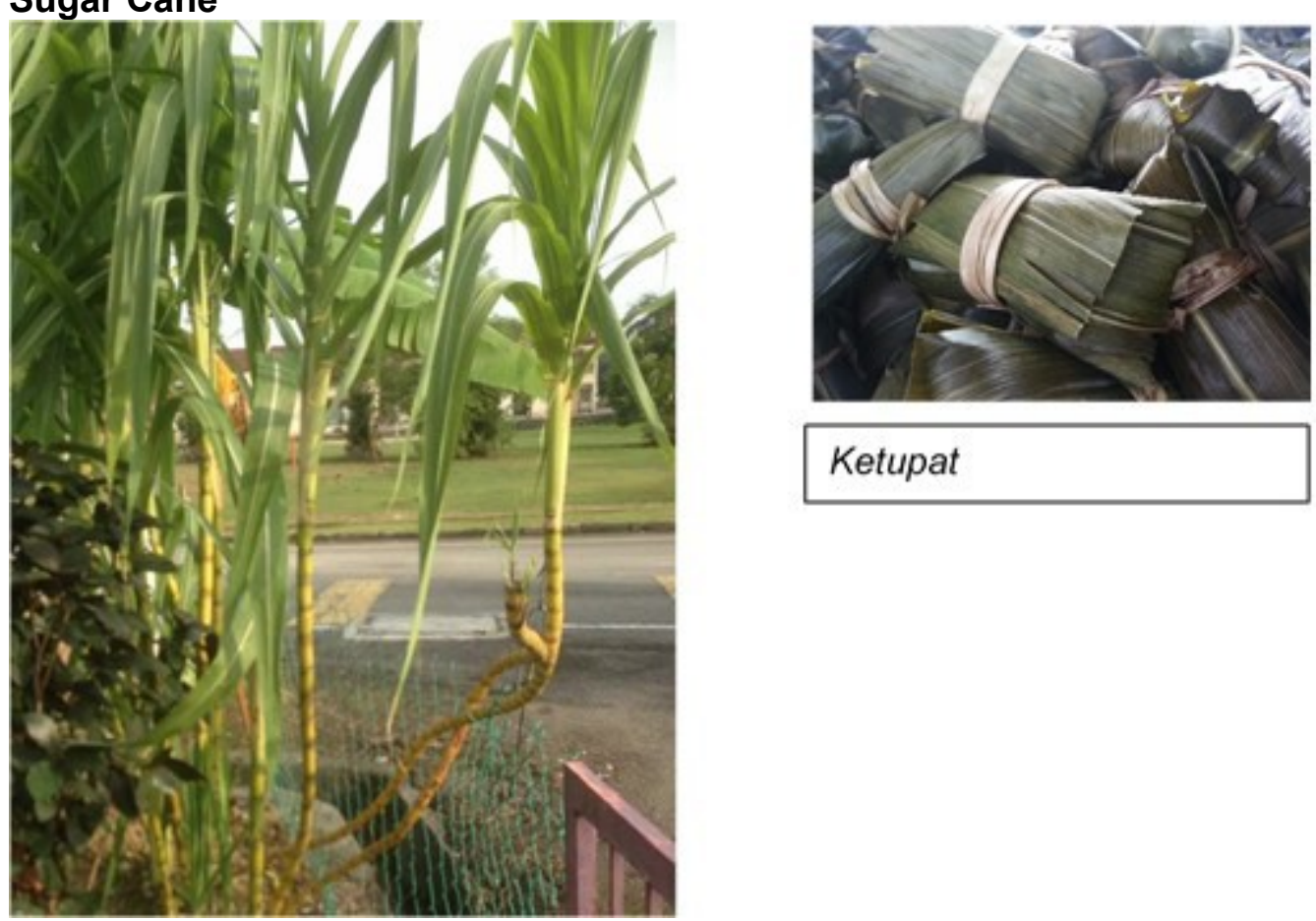

Ketupat

Most of the plants can be used their leaves for traditional food packaging can actually be planted around our homes. The good of these plants indirectly can be used as our landscape, Susette Horspool (2018). The plants also can be arranged as a site walk or pedestrian shelters around the house. Some of these plants can only be planted in pots and can be changed around the home area according to the needs of its residents. In short, this plant does not require extensive plant area.

According to Casey $\mathrm{Ng}$ (2015), for environmental sustainability, the use of leaves makes sense. They are organic; they add an individual touch to food packaging because one has to observe the character of each leaf before folding it. They keep alive the traditions that make us different from the rest of the world. 


\section{FINDING AND CONCLUSION}

Through research, findings have shown that only $45 \%$ of households know how to use some leaves to wrap traditional Malay Food. Among the respondents, parents who know how to use natural leaves, only $60 \%$ of them. The remaining $10 \%$ are among children who represent the younger generation. This means that $30 \%$ of children are unusual using natural leaves as a wrapper to prepare their traditional food. The study also shows that only $30 \%$ of the Malay community plants are used by trees to wrap traditional food around their homes.

This condition affects the importance of research on the use of natural ingredients as a traditional Malay food wrapper, as cultural practices can produce something of artistic value, as well as a symbol of cultural expression and good practice. It turns out so far, people need to be re-conscious so they understand the meaning behind the cultural and social activities around them. Such traditional food preparation needs to be supported by planting the necessary trees around the house for use as a traditional food wrap. Make these trees as the landscape of our home. This will make it easier for a family to practice and teach this culture to their children as a cultural heritage in the future. 


\section{REFERENCES}

A. Ghafar Ahmad (2004), Urban Conservation in Malaysia: Safeguarding Cultural Heritage for Tourism Development. Paper Presented at Seminar Budaya, Pemuliharaan dan Warisan di Malaysia. Fakulti Ecologi Malaysia, Universiti Putra Malaysia, 30 September 2004.

Abdullah A Badawi (2007), Pertahan budaya, kesenian bangsa, Berita Harian, Malaysia, 10 April 2007, pg. 2].

Akta Warisan Kebangsaan (2005) (Akta 645), Jabatan Warisan Negara, Kementerian Kebudayaan, Kesenian, dan Warisan (KeKKWA). Kuala Lumpur.

Bill, S. (2007), Packaging Design, Laurence King Publishing, UK

Casey Ng (2015), Plant Leaves in Food Preparation and Packaging, UTAR Agriculture Science Journal, Oct., 2015.

Gordon, L. R. (2005), Food Packaging: Principles and Practice, Marcel Dekker Inc, New York, USA.

Groth, C. (2006), Exploring Package Design - The Art and Techniques of Designing Exceptional Packaging, Thomson Delmar Learning, Canada

Hasanah (Dr.) (2008), Anyam Ketupat: Seni Kraftangan yang dilupakan, www.Dr Hasanah .com

Hashim Hj. Musa (2005), Pemerkasaan Tamadun Melayu Malaysia Menghadapi Globalisasi Barat, Penerbit Universiti Malaya, Kuala Kumpur.

Hideyuki Oka (2008), How to Wrap Five Eggs: Traditional Japanese Packaging, Weatherhill, Boston. https://dengarden.com., Susette Horspool (2018). How to Plant Tree in Your Landscape.

Marzita Puteh, Sadiah Baharom, Jamilah Omar (2007), Pemikiran Saintifik dan Matematik dalam Kraf Anyaman Buluh Melayu Tradisional: Satu Kajian Kes, Jurnal Peradaban Melayu, Jilid 5, Tahun 2007, Universiti Pendidikan Sultan Idris, Tg. Malam.

Nik Hassan Suhaimi Nik Abd Rahman (2005), Aspek-aspek Tamadun Melayu: Perkembangan dan Perubahan, (Seminar Warisan Seni Bangsa: Bicara Warisan Khazanah Jiwa), Upena, UiTM Shah Alam.

Noor Nikman Salleh (2009). Bab 2: Impak Globalisasi, Seni dan Kebudayaan, Universiti Teknologi Malaysia.

Rahmat Awang (Prof. Madya) (2006), Bahaya Bahan Kimia Dalam Pembungkusan Plastik, Pusat Racun Negara, USM.

S. M. Mohamed Idris (2006), Ketupat Segera Dalam Plastik boleh Akibat Kanser, Utusan Malaysia, 2 November 2007, pg. 9].

Siti Zainon Ismail (1986), Rekabentuk Kraftangan Melayu Tradisi, Dewan Bahasa dan Pustaka, Kuala Lumpur.

Wan Hashim Wan Teh (1998), Nilai Budaya Masyarakat Desa, Kajian Etnografi di Wang Kelian, Perlis, DBP.

Yuriko Saito (2007), Everyday Aesthetics, Oxford University, NY http//:www.AbsoluteAstronomy.com (2009). 